\title{
WYKORZYSTANIE BADAŃ NAD DOSTECPNOŚCIĄ TRANSPORTOWĄ DO OCENY WARTOŚCI CZASU W TRANSPORCIE
}

\section{Wstęp}

Do głównych determinant rozwoju gospodarczego zalicza się sprawne funkcjonowanie systemu transportowego, które można oceniać na podstawie wielu wskaźników. Dostępność transportowa jest jednym z kompleksowych narzędzi, dzięki którym możliwa jest rzetelna analiza stanu systemów transportowych funkcjonujących w danych obszarach geograficznych. Kompleksowość ta wynika z różnorodności typów dostępności transportowej oraz dużej liczby czynników i wskaźników kształtujących jej rodzaje.

Tezą artykułu jest stwierdzenie, że badania nad dostępnością transportową, oprócz szerokiego zastosowania $\mathrm{w}$ różnorodnych dokumentach strategicznych obejmujących koncepcje rozwojowe regionów i całych krajów, mogą być wykorzystywane do próby oceny ekonomicznej wartości czasu w transporcie. Ocena ta jest istotna $\mathrm{w}$ odniesieniu do potencjalnych oszczędności, jakie mogą wynikać $\mathrm{z}$ redukcji czasu transportu, co bezpośrednio wiąże się również z użytecznością takich badań w kontekście decyzji o realizacji szeregu inwestycji infrastrukturalnych. $Z$ drugiej zaś strony sama wycena czasu poświęcanego na transport może wpływać na ocenę dostępności transportowej regionu, która to miara składa się z wielu wskaźników opisujących m.in. czas i koszt przemieszczania.

W pierwszej części opracowania scharakteryzowano pojęcie i rodzaje dostępności transportowej. W dalszej kolejności przedstawiono jej wykorzystanie w badaniach dotyczących obszarów znajdujących się na terenie Polski oraz odnoszących się do całego kraju, z perspektywy europejskiej. Trzecia część artykułu została poświęcona problematyce ekonomicznej wartości czasu w transporcie. W zakończeniu opracowania podjęto próbę wykazania użyteczności poszczególnych rodzajów dostępności transportowej w kontekście szacowania wartości czasu $\mathrm{w}$ transporcie oraz realnego wpływu wyceny czasu w transporcie na poziom różnych rodzajów dostępności transportowej regionów.

* Asystentka, Katedra Badań Porównawczych Systemów Transportowych, Wydział Ekonomiczny, Uniwersytet Gdański. 


\section{Pojęcie i rodzaje dostępności transportowej}

Dostępność transportowa to cecha obszaru, który reprezentowany jest przez konkretny punkt sieci transportowej. Cecha ta określa miary i standard oddalenia przestrzennego pomiędzy regionami lub punktami ${ }^{1}$. Czynnikami kształtującymi dostępność transportową są więc położenie obszaru i jego wyposażenie w infrastrukturę, a co za tym idzie, istnieje silne powiązanie dostępności z wybieraną gałęzią i środkiem transportu oraz $\mathrm{z}$ odległością przestrzenną dzielącą dwa badane punkty ${ }^{2}$. Istnieje możliwość dwojakiego interpretowania dostępności transportowej. $Z$ jednej strony jest to fizyczna zdolność dotarcia do obszaru lub punktu, z drugiej można uznać ją za realną, dającą opisać się w kategoriach kosztu, czasu i standardu, możliwość znalezienia się w określonym czasie i miejscu. Dostępność fizyczna mierzona jest w wymiarze materialnym - określa ją stan infrastruktury. Realną dostępność transportową wyznacza natomiast jakość i rodzaj połączeń komunikacyjnych ${ }^{3}$.

Dostępność transportowa jest szacowana i określana za pomocą różnorodnych mierników, jednak nie wszystkie są wystarczająco precyzyjne w kontekście analiz dostępności transportowej obszaru. Do najczęściej stosowanych wskaźników należą:

- czas podróży,

- wyposażenie w infrastrukturę,

- koszt transportu,

- dostępność dzienna,

- dostępność potencjalna ${ }^{4}$.

Czas potrzebny na dotarcie do najbliższego węzła transportowego oraz wskaźniki wyposażenia obszaru w infrastrukturę, wyrażające się w długości infrastruktury liniowej i ilości infrastruktury punktowej, zaliczane są do wskaźników prostych. Prezentują ważne informacje o transporcie regionu, lecz zawodzą w przypadku badania sieciowego charakteru infrastruktury transportowej łączącej analizowane obszary, nie nawiązując do powiązań pomiędzy nimi.

${ }^{1}$ J. Friedberg, Dostępność terytorialna Polski Wschodniej i korytarze krajowe wiążace ten region z Europa oraz prowadzace do dostępności przestrzennej wszystkich ośrodków powiatowych, http://www.mrr.gov.pl/rozwoj_regionalny/poziom_regionalny/strategia_rozwoju_polski_ wschodniej_do_2020/dokumenty/Documents/d05cda0418e34b6eba9604dbf9c5d3a9Friedberg.pdf (dostęp 20.05.2013), s. 68.

${ }^{2}$ A. Koźlak, Dostępność transportowa jako koncepcja integrujaca planowanie przestrzenne z rozwojem transportu, [w:] S. Korenik, Z. Przybyła (red.), Gospodarka przestrzenna XII, t. I, Stowarzyszenie na Rzecz Promocji Dolnego Śląska, Wrocław 2009, s. 1.

${ }^{3}$ A. Grzelakowski, Dostępność transportowa regionów jako element ich potencjału rozwojowego, „Przegląd Komunikacyjny” 2003, nr 04, s. 11-16.

${ }^{4}$ A. Koźlak, Poprawa dostępności regionów peryferyjnych $w$ świetle polityki spójności Unii Europejskiej, Uniwersytet Gdański, Gdańsk 2007, s. 2. 
Wskaźniki proste nie uwzględniają kilku aspektów jednocześnie, takich jak przykładowo czas i koszty podróży ${ }^{5}$.

Złożone wskaźniki dostępności transportowej ułatwiają wskazanie różnic pomiędzy siecią transportową a miejscami, do których można potencjalnie dotrzeć dzięki tej sieci. Wszystkie złożone wskaźniki zbudowane są z dwóch funkcji. Pierwszą z nich jest funkcja działalności (opisująca możliwości lub działalności, do których dociera się za pomocą sieci - najczęściej jest to wielkość populacji danego obszaru lub PKB), a drugą funkcja utrudnienia (uwzględniająca wysiłek - czas, koszt lub odległość, który trzeba wykonać, aby osiągnąć możliwość opisaną przez pierwszą funkcję). Dostępność transportowa jest więc sumą możliwości dostępnych dla regionu, podzieloną przez łatwość dotarcia do nich ${ }^{6}$.

$\mathrm{Na}$ podstawie sposobu obliczania dostępności transportowej za pomocą wskaźników złożonych wyróżnia się trzy jej podstawowe rodzaje - czasową (kosztową), dzienną i potencjałową. Wymienione rodzaje dostępności powstały dzięki wykorzystaniu jako kryterium podziału omówionych funkcji utrudnienia, którymi są odpowiednio koszt, czas i odległość 7 .

Wskaźniki kosztów podróży określają całkowity lub przeciętny koszt przemieszczenia się do zbiorów celów. Pod pojęciem kosztu można rozumieć także czas potrzebny na przemieszczenie. Dostępność czasowa, również mierzona dla celu lub celów podróży, nazywana jest inaczej dostępnością izochronową. Ta alternatywna nazwa wynika ze sposobu przeprowadzania analizy, polegającym na wykorzystaniu izochron - linii łączących punkty w regionie, które znajdują się w takiej samej odległości czasowej od źródła podróży. Na oszacowanie przeciętnej prędkości wykorzystywanej w tego typu modelach wpływa szereg zmiennych, a zaliczyć do nich można kategorię drogi, liczbę ludności i odsetek obszaru zabudowanego w określonej odległości od drogi, ukształtowanie terenu czy szerokość jezdni i stan nawierzchni ${ }^{8}$.

Dostępność dzienna wiąże się z koncepcją podróży trwającej jeden dzień - dotyczy obszarów osiągalnych w ramach przemieszczeń jednodniowych, w których przejazd w jedną stronę mieści się w przedziale 3-5 godzin. Dostępność dzienna bazuje na wskaźnikach dostępności czasowej, wykorzystując zarazem elementy organizacyjne takie jak rozkłady jazdy ${ }^{9}$. $Z$ tego względu należy upatrywać pewną przewagę dostępności dziennej nad czasową, która

${ }^{5}$ P. Rosik, Efekty redystrybucyjne zmian regionalnej dostępności transportowej, ,Studia Regionalne i Lokalne" 2006, nr 1(23), s. 66.

${ }^{6}$ Ibidem.

${ }^{7}$ Ibidem.

${ }^{8}$ T. Komornicki (red.), P. Rosik, M. Stępniak, Dostępność transportowa Polski. Analiza dostępności transportowej w poszczególnych gałęziach transportu, Polska Akademia Nauk, Instytut Geografii i Przestrzennego Zagospodarowania im. S. Leszczyckiego, Warszawa 2010, s. 1.

${ }^{9}$ Ibidem, s. 2. 
wynika z faktu, iż uwzględnia się w niej różnice pomiędzy odległymi i sąsiednimi regionami. Dodatkową przewagą jest branie pod uwagę stanu infrastruktury transportu - jej rozbudowy i modernizacji, co ma faktyczny wpływ na czas podróży. Kluczową wadą staje się natomiast sztywny czas przejazdu zakładany w badaniach, w rzeczywistości wahający się jednak o nawet kilka godzin. Uwzględnianie tak dużych różnic czasowych ma znaczenie przy podejmowaniu decyzji inwestycyjnych, których podstawą często są wskaźniki budujące pojęcie dostępności transportowej ${ }^{10}$.

Bardziej złożonym miernikiem jest dostępność potencjałowa, nazywana też w wielu opracowaniach potencjalną (potential accessibility), dzięki której możliwe staje się precyzyjniejsze określenie dostępności transportowej. Wynika to $\mathrm{z}$ formuły wskaźnika, która zawsze zawiera $\mathrm{w}$ sobie interakcje przestrzenne i pozwala na odniesienie poziomu infrastruktury do potrzeb społecznych i gospodarczych. Obliczanie dostępności potencjalnej wiąże się najczęściej z wykorzystaniem danych dotyczących różnych gałęzi transportu. Ta międzygałęziowa dostępność określana jest natomiast mianem syntetycznej miary wzajemnej dostępności, która uwzględnia najważniejsze gałęzie transportu wybierane proporcjonalnie do ich udziału $\mathrm{w}$ ogólnej pracy przewozowej oraz poziom rozwoju społeczno-gospodarczego ${ }^{11}$. Z uwagi na istniejące powiązania dostępności międzygałęziowej $\mathrm{z}$ dostępnością potencjalną oraz cechy wskaźników wykorzystywanych do budowania każdej z nich, można uznać je za najbardziej miarodajne rodzaje dostępności wykorzystywane w analizach przestrzennych.

Istnieje wiele innych kryteriów podziału dostępności transportowej niekoniecznie bazujących na wskaźnikach potrzebnych do jej oszacowania. Należy pamiętać, że ich podział nie generuje zupełnie odmiennych rodzajów dostępności, lecz dzieli istniejące miary na różne sposoby, pokazując ich wielowymiarowość i wzajemną komplementarność. Do pozostałych rodzajów dostępności transportowej zalicza się m.in.:

- lokalną - odnoszącą się najczęściej do miasta lub aglomeracji;

- regionalną i interregionalną - wykazujące różnice pomiędzy centrami regionów, a ich peryferiami;

- wewnętrzną i zewnętrzną - definiowaną odpowiednio wewnątrz analizowanego obszaru i z innych regionów do konkretnego obszaru ${ }^{12}$.

Syntetycznie przedstawione pojęcie dostępności transportowej, dzięki swojej złożoności i kompleksowości, jest wykorzystywane jako kluczowe narzędzie

${ }^{10}$ P. Rosik: Efekty redystrybucyjne..., s. 67.

${ }^{11}$ T. Komornicki (red.), Opracowanie metodologii liczenia wskaźnika międzygatęziowej dostępności transportowej terytorium Polski oraz jego oszacowanie. Opracowanie dla Ministerstwa Rozwoju Regionalnego, Polska Akademia Nauk, Instytut Geografii i Przestrzennego Zagospodarowania im. S. Leszczyckiego, Warszawa 2008, s. 6.

${ }^{12}$ P. Rosik, Efekty redystrybucyjne..., s. 68. 
w planowaniu rozwoju transportu ${ }^{13}$. Miara ta jest również najczęściej stosowana do oceny efektywności inwestycji infrastrukturalnych oraz systemów transportowych - ich układów i jakości, a ponadto staje się pomocna w przeprowadzaniu symulacji efektów przyszłych inwestycji transportowych ${ }^{14}$. Dostępność transportowa to również podstawowy czynnik decydujący o atrakcyjności inwestycyjnej danego obszaru, co przejawia się w podejściu potencjalnych inwestorów, którzy zwracają uwagę na możliwość czerpania korzyści z optymalnego czasu i kosztu przewozów towarów oraz osób ${ }^{15}$.

\section{Badania nad dostępnością transportową wybranych obszarów geograficznych Polski}

Analizując dostępność transportową kraju z różnych perspektyw, warto wskazać czynniki, które wpływają na nią w największym stopniu. Istotna jest w tym wypadku zarówno dostępność do stolicy Polski, powiązania międzyregionalne (skomunikowanie pomiędzy ośrodkami wojewódzkimi), jak i wyposażenie w infrastrukturę transportową o znaczeniu krajowym. Do gałęzi transportu o największym znaczeniu $\mathrm{w}$ kontekście powiązań wewnątrzkrajowych należy transport drogowy, kolejowy oraz lotniczy. Wymienione gałęzie zostały wzięte pod uwagę w badaniu dotyczącym dostępności transportowej regionów w Polsce na poziomie NTS2 przeprowadzonym w 2007 r., którego wyniki zostały przedstawione w tabeli 1. Zawarto w niej dane liczbowe, które otrzymano dzięki zastosowaniu metody standaryzowanych wartości. Zmienne wykorzystane w badaniu odnoszą się do trzech wymienionych powyżej gałęzi transportu i opisują gęstość sieci komunikacyjnych, ich przepustowość, czas przejazdu do Warszawy oraz inne cechy charakterystyczne poszczególnych gałęzi transportu w województwach ${ }^{16}$.

Według danych zestawionych $\mathrm{w}$ tabeli 1 najlepsze wyniki w poszczególnych kategoriach dostępności osiągnęło województwo mazowieckie (pod względem ogólnej dostępności transportowej oraz dostępności lotniczej), województwo śląskie (dostępność kolejowa) i województwo opolskie (dostępność drogowa). Najlepsze wyniki oznaczono w tabeli szarym, jednolitym kolorem tła. Warto nadmienić, że województwo mazowieckie oraz śląskie uplasowało się

${ }^{13}$ A. Koźlak, Dostępność transportowa..., s. 3.

${ }^{14}$ T. Komornicki, P. Rosik, M. Stępniak, Dostępność transportowa..., s. 1.

${ }^{15}$ T. Kalinowski (red.), Atrakcyjność inwestycyjna województw i podregionów Polski 2006, Instytut Badań nad Gospodarką Rynkową, Fundacja Konrada Adenauera, Gdańsk 2006, s. 25.

${ }^{16}$ A. Koźlak, Zastosowanie metod taksonomicznych do oceny zróżnicowania dostepności transportowej regionów na przykładzie Polski, [w:] E. Załoga (red.), Dostępność transportowa, aspekty teoretyczne i praktyczne, „Zeszyty Naukowe” 2009, nr 538, Ekonomiczne Problemy Usług nr 33, Szczecin, s. 48. 
wraz z wielkopolskim w grupie województw o najwyższej klasie dostępności transportowej oznaczonej literą A. Poszczególne klasy zostały zdefiniowane za pomocą następujących nierówności odnoszących się do wskaźnika dostępności transportowej (DT):

- klasa A, gdy DT $\geq 0,3$

- klasa B, gdy $0,3>\mathrm{DT} \geq 0$

- klasa C, gdy $0>\mathrm{DT} \geq-0,3$

- klasa D, gdy DT $<-0,3^{17}$.

Tabela 1. Dostępność transportowa województw w Polsce w 2007 r.

\begin{tabular}{|c|l|c|c|c|c|c|}
\hline $\begin{array}{c}\text { Pozycja } \\
\text { w } \\
\text { rankingu }\end{array}$ & Województwo & $\begin{array}{c}\text { Dostępność } \\
\text { drogowa }\end{array}$ & $\begin{array}{c}\text { Dosteppność } \\
\text { kolejowa }\end{array}$ & $\begin{array}{c}\text { Dostępność } \\
\text { lotnicza }\end{array}$ & $\begin{array}{c}\text { Wskaźnik } \\
\text { dostępności } \\
\text { transportowej } \\
\text { (DT) }\end{array}$ & $\begin{array}{c}\text { Klasa } \\
\text { dostępności }\end{array}$ \\
\hline 1 & Mazowieckie & $-0,06$ & 0,50 & 1,51 & $\mathbf{0 , 5 8}$ & A \\
\hline 2 & Śląskie & $-0,09$ & 0,98 & 0,48 & 0,40 & A \\
\hline 3 & Wielkopolskie & 0,09 & 0,37 & 0,7 & 0,36 & A \\
\hline 4 & Dolnośląskie & 0,17 & $-0,01$ & 0,65 & 0,26 & B \\
\hline 5 & Opolskie & 0,51 & 0,44 & $-0,28$ & 0,25 & B \\
\hline 6 & Lódzkie & $-0,07$ & 0,67 & 0,06 & 0,19 & B \\
\hline 7 & Małopolskie & $-0,33$ & 0,07 & 0,86 & 0,15 & B \\
\hline 8 & $\begin{array}{l}\text { Kujawsko- } \\
\text { pomorskie }\end{array}$ & $-0,16$ & $-0,10$ & 0,40 & 0,03 & B \\
\hline 9 & Świętokrzyskie & 0,18 & 0,33 & $-0,57$ & 0,00 & B \\
\hline 10 & Lubuskie & 0,42 & $-0,10$ & $-0,76$ & $-0,09$ & C \\
\hline 11 & Pomorskie & $-0,42$ & $-0,57$ & 0,71 & $-0,12$ & C \\
\hline 12 & Zachodniopomorskie & $-0,13$ & $-0,29$ & $-0,45$ & $-0,27$ & C \\
\hline 13 & $\begin{array}{l}\text { Warmińsko- } \\
\text { mazurskie }\end{array}$ & 0,24 & $-0,25$ & $-1,10$ & $-0,31$ & D \\
\hline 14 & Lubelskie & 0,07 & $-0,42$ & $-0,73$ & $-0,32$ & D \\
\hline 15 & Podlaskie & $-0,06$ & $-0,73$ & $-0,99$ & $-0,54$ & D \\
\hline 16 & Podkarpackie & $-0,37$ & $-0,91$ & $-0,49$ & $-\mathbf{0 , 5 7}$ & D \\
\hline
\end{tabular}

Źródło: opracowanie własne na podstawie: A. Koźlak, Zastosowanie metod taksonomicznych do oceny zróżnicowania dostępności transportowej regionów na przykładzie Polski, [w:] E. Załoga (red.), Dostępność transportowa, aspekty teoretyczne i praktyczne, „Zeszyty Naukowe” 2009, nr 538, Ekonomiczne Problemy Usług nr 33, Szczecin, s. 48.

\footnotetext{
${ }^{17}$ Ibidem, s. 48.
} 
Dane zestawione w tabeli $1 \mathrm{w}$ komórkach o zakreskowanym tle to najsłabsze wyniki w poszczególnych zbadanych kategoriach dostępności. Najniższą dostępnością drogową charakteryzowało się w 2007 r. województwo pomorskie, w którym odnotowano małą gęstość dróg wewnątrz obszaru i brak połączeń drogami krajowymi i autostradą z Warszawą i innymi większymi miastami w kraju i Europie. Najniższym współczynnikiem dostępności lotniczej charakteryzowało się województwo warmińsko-mazurskie peryferyjnie położone w stosunku do największych portów lotniczych w kraju. Województwo podkarpackie to obszar o najniższej dostępności kolejowej oraz najniższym wskaźniku multimodalnej dostępności transportowej. Wraz z województwem warmińskomazurskim, lubelskim i podlaskim tworzą grupę czterech województw o najniższym wskaźniku dostępności transportowej (grupa D). Można wnioskować, że kwestia poprawy dostępności na wymienionych obszarach wschodniej Polski jest priorytetem, co bezpośrednio wiąże się z koniecznością precyzyjnej identyfikacji potrzeb w zakresie inwestycji infrastrukturalnych.

Dostępność transportowa do stolicy - ośrodka gospodarczego - jest określana mianem kluczowej miary obrazującej integralność społeczno-gospodarczą przestrzeni kraju. Rysunek 1 przedstawia mapy dostępności drogowej i kolejowej do Warszawy stworzone na potrzeby opracowania Instytutu Geografii i Przestrzennego Zagospodarowania PAN. Omawiana czasowa dostępność transportowa do stolicy została zobrazowana na mapach Polski, na których można zidentyfikować nierównomierne rozłożenie układu izochron wokół Warszawy. Należy podkreślić, iż o spójnej infrastrukturze transportowej świadczy równomierna dostępność transportowa do danego punktu mierzona z różnych kierunków geograficznych, czego na podstawie przedstawionych map nie można powiedzieć o polskiej sieci drogowej i kolejowej ${ }^{18}$.

Warunki wzrastającej mobilności globalnej sprawiają, że istotne jest badanie pozycji Polski i jej regionów w kontekście dostępności do europejskiej i światowej przestrzeni gospodarczej. W tym wypadku również duże znaczenie ma analiza różnych gałęzi transportu, które mają wpływ na szybkość i jakość połączeń międzynarodowych. Oprócz sieci drogowej i kolejowej ważne są przewozy osób i ładunków transportem lotniczym i morskim. Warto nadmienić, że mimo atutów związanych z nadmorskim położeniem Polski dostępność transportowa z perspektywy krajów europejskich do województwa pomorskiego i zachodniopomorskiego jest niższa od przeciętnych wartości tych mierników charakteryzujących inne regiony nadmorskie w Europie ${ }^{19}$.

${ }^{18}$ T. Komornicki, P. Rosik, M. Stępniak, Dostępność transportowa..., s. 4-5.

19 J. Burnewicz, Spójny i innowacyjny system transportowy Pomorza, Wydawnictwo UG, Gdańsk 2011, s. 12. 


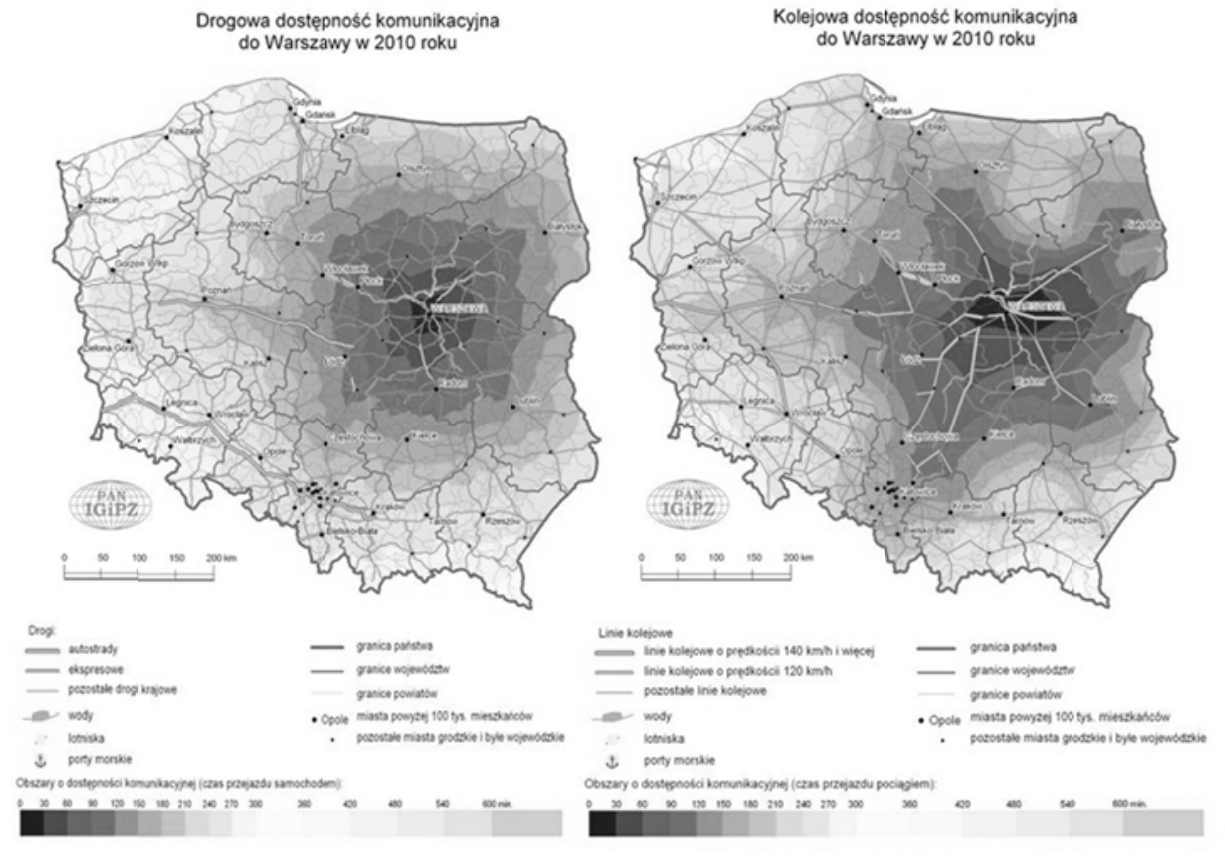

Rysunek 1. Drogowa i kolejowa dostępność czasowa do Warszawy (2010)

Źródło: T. Komornicki (red.), P. Rosik, M. Stępniak, Dostępność transportowa Polski. Analiza dostępności transportowej w poszczególnych gatęziach transportu, Polska Akademia Nauk, Instytut Geografii i Przestrzennego Zagospodarowania im. S. Leszczyckiego, Warszawa 2010, s. 4-5.
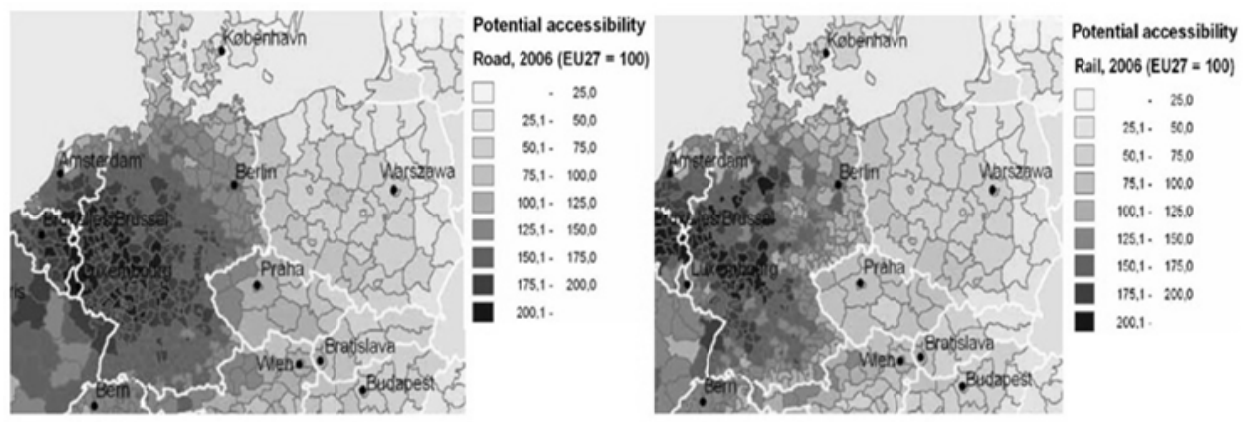

Rysunek 2. Drogowa i kolejowa dostępność transportowa Polski w 2006 r. w perspektywie europejskiej

Źródło: opracowanie własne na podstawie: Spiekermann \& Wegener, Update of Selected Potential Accessibility Indicators, Final Report 2007, Urban and Regional Research (S\&W), RRG Spatial Planning and Geoinformation, 2007, http://www.espon.eu/export/sites/default/Documents/ Projects/ESPON2006Projects/ScientificBriefingNetworking/UpdateOnAccessibilityMaps/espon _accessibility_update_2006_fr_070207.pdf(dostęp 02.06.2013), s. 16, 21. 
Według badań przeprowadzonych w ramach ESPON, drogowa i kolejowa dostępność potencjałowa w Europie w 2006 r. potwierdzała peryferyjną lokalizację Polski na tle krajów członkowskich UE. Jak widać na rysunku 2 wszystkie obszary, włącznie z leżącymi wzdłuż zachodniej granicy kraju, znajdują się w trudno dostępnym położeniu drogowym i kolejowym w porównaniu z centralną częścią kontynentu zwaną Pentagonem. Przeciętnie obszar Polski charakteryzuje się około dwukrotnie mniejszymi wskaźnikami dostępności w stosunku do średniej UE-27, Pentagon natomiast około dwukrotnie większymi od przeciętnej. Według badań przeprowadzonych przez Instytut Geografii i Przestrzennego Zagospodarowania PAN, czasowa dostępność samochodowa do granicy niemieckiej utożsamiana $\mathrm{z}$ dostępnością do rdzenia Unii Europejskiej wynosiła w 2010 r. od 2 godzin podróży ze wschodniej granicy województw zachodniopomorskiego, wielkopolskiego i dolnośląskiego do 10 godzin ze wschodnich granic województw warmińsko-mazurskiego, podlaskiego, lubelskiego i podkarpackiego ${ }^{20}$.

Jak już wspomniano, istotnym czynnikiem wpływającym na ostateczny kształt dostępności transportowej regionu jest jakość powiązań międzyregionalnych, którą można traktować tożsamo z dostępnością do ośrodków wojewódzkich. Polska charakteryzuje się dużą ilością obszarów, z których czas podróży do stolic własnych regionów jest za długi. Wzmocnienie powiązań pomiędzy największymi polskimi aglomeracjami to jeden z priorytetowych zapisów Koncepcji Przestrzennego Zagospodarowania $\mathrm{Kraju}^{21}$. Nie ulega wątpliwości, że działania dążące do budowania integralności infrastrukturalnej największych ośrodków miejskich to krok do stworzenia konkurencyjnych w Europie metropolii sieciowych. Zakłada się, że czas podróży do najbliższych większych aglomeracji nie powinien przekraczać granicy trzech godzin, co pozwala na odbywanie wygodnych podróży jednodniowych (np. do pracy) ${ }^{22}$.

Analiza przykładowych badań nad dostępnością transportową pozwala stwierdzić, że są one źródłem wielu cennych informacji na temat systemów transportowych poszczególnych obszarów. Informacje te mogą być wykorzystywane $\mathrm{w}$ dalszych analizach, również tych dotyczących wyceny ekonomicznej wartości czasu w transporcie.

${ }^{20}$ T. Komornicki, P. Rosik, M. Stępniak, Dostępność transportowa ..., s. 19.

${ }^{21}$ Koncepcja przestrzennego zagospodarowania kraju 2030, Ministerstwo Rozwoju Regionalnego, Warszawa, 2013, http://www.mrr.gov.pl/rozwoj_regionalny/Polityka_przestrzenna/ KPZK/Aktualnosci/Documents/KPZK2030.pdf (dostęp 02.06.2013), s. 106.

${ }^{22}$ T. Komornicki, P. Rosik, M. Stępniak, Dostępność transportowa ..., s. 6-7. 


\section{Ekonomiczna wartość czasu w transporcie}

Czas można nazwać zasobem nieodnawialnym, którego wielowymiarową wartość niełatwo jest oszacować. Ekonomiczna kalkulacja wartości czasu łatwiej przychodzi przedsiębiorcom zatrudniającym pracowników niż stronie popytowej, będącej przecież bardzo często narażoną na nadmierną utratę czasu podczas transportu. Zjawisko kongestii na sieciach transportowych powoduje utratę czasu, który potencjalnie mógłby być poświęcony na pracę lub odpoczynek. Obie utracone możliwości, a właściwie ich koszt, można w pewnym stopniu analizować w kategoriach ekonomicznych, gdyż wpływają one na jakość życia ${ }^{23}$.

$\mathrm{W}$ teorii ekonomii wartość czasu $\mathrm{w}$ transporcie jest $\mathrm{z}$ jedną $\mathrm{z}$ istotnych kategorii kosztów transportu. Ekonomiczną wartością czasu w transporcie możemy nazwać koszt, jaki użytkownik skłonny jest ponieść, aby skrócić czas podróży czy przewozu lub wartość korzyści materialnych i niematerialnych, jakie byłby skłonny przyjąć w ramach rekompensaty za czas utracony podczas procesu transportowego (koszt utraconych korzyści) ${ }^{24}$. Wartość czasu w transporcie to inaczej koszt czasu przeznaczonego na przemieszczanie, włącznie z czasem oczekiwania - czasem dodatkowo spędzonym w podróży z powodu zaistnienia szeregu czynników zewnętrznych, takich jak specyficzne warunki atmosferyczne czy wspomniane wcześniej zjawisko kongestii.

Według danych przedstawionych w opracowaniu Victoria Transport Policy Institute z 2012 r. ludzie na całym świecie poświęcają na podróże średnio 60-90 minut dziennie. Szacowanie kosztów czasu tych podróży nie jest łatwe ze względu na mocno zróżnicowane czynniki, do których należą przede wszystkim warunki podróży oraz sposoby i możliwości wykorzystywania czasu podczas transportu na inne aktywności. Inny będzie koszt jednostkowy w przypadku użytkowników transportu zbiorowego oczekujących na transport w głośnym miejscu $\mathrm{z}$ narażeniem na niedogodne warunki atmosferyczne, a inny - dla użytkownika prywatnego samochodu podróżującego po niewielkiej miejscowości nieobarczonej zjawiskiem kongestii ${ }^{25}$.

${ }^{23}$ L. Dowbor, Wartość ekonomiczna czasu wolnego, 2010, http://dowbor.org/12czaswolny. doc (dostęp 02.05.2013), s. 1.

${ }^{24}$ Raport o korkach $w 7$ największych miastach Polski, Warszawa, Lódź, Wrocław, Kraków, Katowice, Poznań, Gdańsk, rok 2011, Deloitte, Targeo.pl, 2012, http://www.deloitte.com/assets/ Dcom-Poland/Local\%20Assets/Documents/Raporty,\%20badania, \%20rankingi/pl_Raport_Korki 2011_marzec2012.pdf (dostęp 02.06.2013), s. 35.

${ }^{25}$ Transportation Cost and Benefit Analysis II - Travel Time Costs, Victoria Transport Policy Institute, 2012, http://www.vtpi.org/tca/tca0502.pdf (dostęp 02.06.2013), s. 6. 
Tabela 2. Roczny koszt kongestii w 7 największych miastach Polski przypadający na jednego kierowcę w latach 2010-2011

\begin{tabular}{|l|c|c|c|}
\hline \multicolumn{1}{|c|}{ Miasto } & 2010 (PLN) & 2011 (PLN) & 2011-2010 (PLN) \\
\hline Katowice & 1111 & 1396 & 285 \\
\hline Lódź & 1602 & 1590 & -13 \\
\hline Gdańsk & 2356 & 2488 & 132 \\
\hline Poznań & 2475 & 2695 & 220 \\
\hline Kraków & 3345 & 2590 & -755 \\
\hline Wrocław & 2746 & 2634 & -112 \\
\hline Warszawa & 4312 & 4389 & 77 \\
\hline Średnia & $\mathbf{2 8 3 7}$ & $\mathbf{2 8 1 1}$ & $\mathbf{- 2 6}$ \\
\hline
\end{tabular}

Źródło: Raport o korkach $w 7$ największych miastach Polski, Warszawa, Łódź, Wrocław, Kraków, Katowice, Poznań, Gdańsk, rok 2011, Deloitte, Targeo.pl, 2012, dostępne w internecie [http://www.deloitte.com/assets/Dcom-Poland/Local\%20 Assets/Documents/Raporty,\%20badania,\%20rankingi/pl_Raport_ Korki2011_marzec2012.pdf] (dostęp 02.06.2013), s. 36.

Ze względu na wiele utrudnień związanych z dokładną wyceną ekonomicznej wartości czasu $\mathrm{w}$ transporcie, bardzo często obliczenia związane $\mathrm{z}$ tą problematyką są upraszczane. W szacunkach dotyczących kosztów kongestii drogowej wyrażonych w PLN, ponoszonych przez osoby pracujące w siedmiu największych miastach Polski, nie uwzględniono przykładowo kosztów ekologicznych (emisji spalin i $\mathrm{CO}_{2}$ ), kosztów związanych z konsekwencjami zdrowotnymi odczuwanymi przez uczestników ruchu drogowego oraz kosztów wypadków w odniesieniu do budżetu państwa, przedsiębiorstw oraz pojedynczych gospodarstw domowych. Niemniej jednak przytoczone badanie wykonane przez Deloitte i Targeo.pl nie miało na celu maksymalizacji szacowanych kosztów alternatywnych, lecz zobrazowanie skali zjawiska, jakim jest utrata realnych wartości pieniężnych spowodowana przeciążeniem sieci transportowej w największych miastach Polski. Tabela 2 przedstawia wyniki wspomnianych badań, obrazujące roczny koszt kongestii przypadający na jednego kierowcę w latach $2010-2011^{26}$.

Wszystkie osoby pracujące $\mathrm{w}$ siedmiu wymienionych w tabeli 2 miastach straciły z powodu zjawiska kongestii w $2011 \mathrm{r}$. w sumie $3,6 \mathrm{mld}$ zl, co daje $299 \mathrm{mln}$ zł miesięcznie i 13,6 mln zł dziennie. W porównaniu z rokiem 2010 odnotowano zmniejszenie tych kosztów aż o 96 mln zł w odniesieniu do sumy rocznej. Przedstawione badania wykazują, że niewielka zmiana liczona

\footnotetext{
${ }^{26}$ Raport o korkach..., s. 35-36.
} 
w minutach spędzanych na indywidualnych podróżach, przeliczona na wszystkich użytkowników badanych miast, daje efekty o makroekonomicznym znaczeniu $^{27}$. Można wnioskować, że podobne analizy, nawet o zawężonych możliwościach szacunkowych, bardzo dobrze identyfikują obszary, w których koszt transportu jest zbyt wysoki. Badania nad dostępnością transportową mogą przyspieszyć procesy identyfikacji takich miejsc, a sama wycena czasu nadmiernie spędzanego $\mathrm{w}$ transporcie może $\mathrm{w}$ dalszych etapach badań wspomagać precyzyjniejsze określanie miar czasowej, dziennej czy potencjalnej dostępności transportowej.

\section{Zakończenie}

Przedstawiona w artykule analiza wybranych badań nad dostępnością transportową pozwala na identyfikację punktów i obszarów na terenie Polski, które charakteryzują się niedostatecznym wyposażeniem $\mathrm{w}$ infrastrukturę transportową. Wiedza na temat kluczowych problemów w zakresie systemów transportowych jest niezbędna nie tylko w planowaniu rozwoju i modernizacji omawianej infrastruktury, ale również z punktu widzenia prowadzenia odpowiedniej w tym zakresie polityki. Narzędzia w postaci różnych rodzajów omawianej dostępności dostarczają wielu szczegółowych informacji (czas i koszt przewozów, opóźnienia i ich przyczyny), dzięki którym możliwa staje się wycena wartości czasu poświęcanego na transport, będąca jednym z kluczowych elementów przy podejmowaniu decyzji inwestycyjnych. Co więcej, znajomość wartości czasu nadmiernie spędzanego na transporcie z powodu kongestiii innych czynników zewnętrznych, może przyczyniać się do podejmowania bardziej racjonalnych decyzji przez użytkowników transportu - mowa tu przykładowo o wyborze alternatywnych $\mathrm{w}$ stosunku do indywidualnego transportu samochodowego gałęzi takich jak publiczny transport zbiorowy, kolej i inne.

Tezę przedstawioną we wstępie artykułu można uznać za prawdziwą, a kolejnym wnioskiem temu dowodzącym jest stwierdzenie, że oba analizowane w ramach opracowania zagadnienia mogą się wzajemnie uzupełniać. Ocena ekonomicznej wartości czasu w transporcie, nie będąca łatwym zadaniem, które może być realizowane za pomocą wskaźników budujących dostępność transportową, umożliwia też w innym ujęciu udoskonalanie precyzyjności tej miary. Szczegółowe dane dotyczące kosztów wyrażonych w jednostkach pieniężnych mogą wspierać obliczenia funkcji utrudnienia zawartej w formule dostępności transportowej budowanej ze wskaźników złożonych.

\footnotetext{
${ }^{27}$ Ibidem, s. 35.
} 


\section{Literatura}

Burnewicz J., Spójny i innowacyjny system transportowy Pomorza, Wydawnictwo UG, Gdańsk 2011.

Dowbor L., Wartość ekonomiczna czasu wolnego, 2010, (http://dowbor.org/12czaswolny.doc.

Friedberg J., Dostępność terytorialna Polski Wschodniej i korytarze krajowe wiążace ten region z Europa oraz prowadzace do dostęności przestrzennej wszystkich ośrodków powiatowych, $\mathrm{http} / / / w w w . m r r . g o v . p 1 /$ rozwoj_regionalny/poziom_regionalny/strategia_rozwoju_polski_wsc hodniej_do_2020/dokumenty/Documents/d05cda0418e34b6eba9604dbf9c5d3a9Friedberg.pdf.

Grzelakowski A., Dostępność transportowa regionów jako element ich potencjału rozwojowego, „Przegląd Komunikacyjny” 2003, nr 04.

Kalinowski T. (red.), Atrakcyjność inwestycyjna województw i podregionów Polski 2006, Instytut Badań nad Gospodarką Rynkową, Fundacja Konrada Adenauera, Gdańsk 2006.

Komornicki T. (red.), Opracowanie metodologii liczenia wskaźnika międzygatęziowej dostępności transportowej terytorium Polski oraz jego oszacowanie, Opracowanie dla Ministerstwa Rozwoju Regionalnego, Polska Akademia Nauk, Instytut Geografii i Przestrzennego Zagospodarowania im. S. Leszczyckiego, Warszawa 2008.

Komornicki T. (red.), Rosik P., Stępniak M., Dostępność transportowa Polski, Analiza dostępności transportowej w poszczególnych gatęziach transportu, Polska Akademia Nauk, Instytut Geografii i Przestrzennego Zagospodarowania im. S. Leszczyckiego, Warszawa 2010.

Koncepcja przestrzennego zagospodarowania kraju 2030, Ministerstwo Rozwoju Regionalnego, Warszawa 2013, http://www.mrr.gov.pl/rozwoj_regionalny/Polityka_przestrzenna/KPZK/ Aktualnosci/Documents/KPZK2030.pdf.

Koźlak A., Dostępność transportowa jako koncepcja integrująca planowanie przestrzenne z rozwojem transportu, [w:] S. Korenik, Z. Przybyła (red.) Gospodarka przestrzenna XII, t. I, Stowarzyszenie na Rzecz Promocji Dolnego Śląska, Wrocław 2009.

Koźlak A., Poprawa dostępności regionów peryferyjnych $w$ świetle polityki spójności Unii Europejskiej, Uniwersytet Gdański, Gdańsk 2007.

Koźlak A., Zastosowanie metod taksonomicznych do oceny zróżnicowania dostępności transportowej regionów na przykładzie Polski, [w:] E. Załoga (red.), Dostępność transportowa, aspekty teoretyczne $i$ praktyczne, „Zeszyty Naukowe” 2009, $\mathrm{nr}$ 538, Ekonomiczne Problemy Usług nr 33, Szczecin.

Raport o korkach w 7 największych miastach Polski, Warszawa, Łódź, Wroctaw, Kraków, Katowice, Poznań, Gdańsk, rok 2011, Deloitte, Targeo.pl, 2012, http://www.deloitte. com/assets/DcomPoland/Local\%20Assets/Documents/Raporty,\%20badania,\%20rankingi/pl_ Raport_Korki2011_marzec2012.pdf.

Rosik P., Efekty redystrybucyjne zmian regionalnej dostępności transportowej, „Studia Regionalne i Lokalne" 2006, nr 1(23).

Transportation Cost and Benefit Analysis II - Travel Time Costs, Victoria Transport Policy Institute, 2012, http://www.vtpi.org/tca/tca0502.pdf.

\section{Streszczenie}

Celem artykułu jest wykazanie, że badania nad dostępnością transportową mogą być cennym źródłem danych dla wyceny wartości czasu w transporcie, a koszt czasu transportu wyrażony w jednostkach pieniężnych może udoskonalać wyniki badań nad 
dostępnością transportową. Postawiony cel został osiągnięty poprzez scharakteryzowanie rodzajów dostępności transportowej, analizę badań nad dostępnością transportową wybranych regionów geograficznych oraz przybliżenie problematyki szacowania ekonomicznej wartości czasu $\mathrm{w}$ transporcie, która jest istotna $\mathrm{z}$ punktu widzenia planowania inwestycji infrastrukturalnych i generowania oszczędności związanych ze skracaniem czasu przewozu.

\section{Summary}

\section{RESEARCH ON TRANSPORT ACCESSIBILITY FOR ESTIMATING THE VALUE OF TRAVEL TIME}

The aim of this article is to prove that studies on transport accessibility can be a valuable source of data for determining the value of time in transport, and that there is also an inverse relationship - the cost of travel time, expressed in monetary units may improve the results of research on transport accessibility. This thesis has been proven by characterising the types of transport accessibility, analysing research on transport accessibility in selected geographic regions and discussing the issue of estimating the economic value of time in transport. 